Vol. 13, n² | 2009

Varia

\title{
Complain in vain? The development of a 'police complaints culture' in Wilhelmine Berlin
}

Anja Johansen

\section{(2) OpenEdition}

Electronic version

URL: https://journals.openedition.org/chs/1117

DOI: 10.4000/chs. 1117

ISSN: 1663-4837

Publisher

Librairie Droz

Printed version

Date of publication: 1 October 2009

Number of pages: 119-142

ISBN: 978-2-600-01387-1

ISSN: $1422-0857$

\section{Electronic reference}

Anja Johansen, "Complain in vain? The development of a 'police complaints culture' in Wilhelmine Berlin", Crime, Histoire \& Sociétés / Crime, History \& Societies [Online], Vol. 13, n² | 2009, Online since 01 October 2012, connection on 25 March 2022. URL: http://journals.openedition.org/chs/1117 ; DOI: https://doi.org/10.4000/chs. 1117 


\title{
Complain in vain? \\ The development of a 'police complaints culture' in Wilhelmine Berlin
}

\author{
Anja Johansen ${ }^{1}$
}

Cet article examine les relations entre la police et le public dans le Berlin de l'époque wilhelminienne du point de vue des citoyens qui déposèrent plainte auprès du Préfet de police entre 1892 et 1913 et les compare avec la situation de ceux qui s'en prenaient à la Metropolitan Police londonienne. Les plaintes des citoyens révèlent un rapport de force fortement assymétrique entre le plaignant et la police, dans lequel le droit des citoyens à contester les autorités publiques était sévèrement restreint par les pratiques bureaucratiques relatives au traitement des plaintes. En outre, l'engagement officiel de la police à n'opérer que dans les strictes limites du droit était largement miné par le flou des limitations légales des pouvoirs de police. Cela n'empêchait pas les Berlinois de se plaindre massivement. Les plaintes adressées au préfet de police de Berlin donnent ainsi un aperçu de la façon dont des citoyens ordinaires mettaient en cause les autorités policières. Elles montrent qui étaient les plaignants, l'objet de leurs plaintes et leurs résultats. Elles révèlent également comment ils s'y prenaient pour se poser en victime et argumentaient que le policier avait transgressé, sinon la loi, du moins les limites du comportement acceptable.

This article assesses police-public relations in Wilhelmine Berlin from the perspective of those citizens who complained to the Berlin Polizeipräsident between 1892 and 1913. It also makes some comparisons with the position of complainants who challenged London's Metropolitan Police. Citizens' complaints reflect a highly asymmetrical power relationship between the complainant and the police, in which citizens' legal rights to challenge public authorities were severely restricted by bureaucratic practices surrounding the handling complaints. Moreover, the official police commitment to operate strictly within the limits of the law was largely undermined by fluid legal boundaries around police powers. Even so, Berliners complained extensively. The complaints made to the Berlin Polizeipräsident provide insights into how ordinary members of the Berlin public challenged the police authorities. They illustrate who complained, about what and with what effect; and they show how complainants constructed their victimhood and made the case that the policeman had transgressed, if not the law, then at least some boundaries of acceptable behaviour.

1 Dr Anja Johansen, Lecturer on Modern European History at Dundee University. PhD from the European University Institute, Florence, in 1999. Main publication: Soldiers as Police, Aldershot, Ashgate, 2005. She is currently working on a project on citizens' complaints against the police in London, Paris and Berlin, 1870-1914. 


\section{COMPLAINING CITIZENS IN WILHELMINE BERLIN}

$\mathrm{T}$ he complex and often ambiguous relationship between 'ordinary' Prussians and public authorities from the rise to the demise of the Prussian Kingdom has become the object of renewed interest for historians ${ }^{2}$. In addition during the 1980s and 1990s a series of works sought to reinterpret Prussian policing in terms more complex than simply that of an authoritarian, bureaucratic and militarised police force bossing around submissive and disempowered subjects ${ }^{3}$. This article looks at complaints by the citizens of Wilhelmine Berlin against the Berlin Schutzmannschaft. Complainants - as opposed to protesters - adopt non-coercive strategies to express discontent, they play the system 'by the rules' sometimes in rather creative ways, but mostly remain within the limits of legality. Such individual challenges to the public authorities are interesting in revealing important aspects of the complex power relationship between regime and citizens.

Historians have long noted the multiple ambiguities and contradictions in the attitudes towards the political leadership and public authorities, both by the German bourgeoisie ${ }^{4}$ and by members of the lower orders who constituted the main target of the police ${ }^{5}$. While the Prussian authorities of the late nineteenth century had made multiple concessions by placing policing within the boundaries of the law and by some recognition of basic rights to citizens, the venues for challenging the Prussian police remained few and ineffective. The starting point for the present article is the observation that, contrary to the popular myth about the 'submissive Germans', the good citizens of Wilhelmine Berlin were very active in voicing their complaints through the courts, through the press and particularly through letters to the head of the Berlin Schutzmannschaft, insisting on their right to be treated with dignity and within the boundaries of the law.

Although less spectacular than popular protest actions such as strikes, riots or revolts ${ }^{6}$, the motivations and strategies for individual challenges to public authorities were significant as a form of protest. Historians and sociologists working on protest or 'contentious politics' have long sought to broaden the scope of research beyond studies of collective actions, strikes, riots and revolts. Indeed, some of the pioneers within the field have called for a less rigid distinctions between subversive protest and protest that took place with recognised procedures ${ }^{7}$. The attention of historians to police complaints is all the more timely in the light of the increasing amount of research by legal scholars, political scientists and criminologists into contemporary police complaints procedures in the late twentieth and early twenty-first century $^{8}$. While this research has highlighted important aspects of the inherent

MacDonough (1995); Friedrich (2000); Levinger (2000); Clark (2006). See also Dwyer (2000).

Lüdtke (1982); Funk (1986); Jessen (1991); Spencer (1992); Lindenberger (1995).

4 Eley, Blackbourn (1984, pp. 159-175); Evans (1987,pp. 156-218); Nipperdey (1991, pp. 417-420); Repp (2000).

$5 \quad$ Funk (1986, pp. 283-284); Jessen (1991, pp. 179-185); see also Lindenberger (1995).

6 Studies specifically looking at the relationship between protesters and the forces of order notably Lindenberger (1995); Bruneteaux (1996); Fillieule (1997).

7 McAdam, Tarrow, Tilly (2001, pp. 4-7).

8 Bailey (1985, 1991); Goldsmith (1991, 1996); Goldsmith, Lewis (2000); Prenzler, Lewis (2005); Walker (2001); Smith (2006). 
asymmetric power relationship in conflicts between citizens and public authorities in contemporary western democracies, the historical perspective on police complaints generally goes back no further than the 1960s.

On the other hand, while historians of nineteenth-century German policing have paid considerable attention to the conflict-ridden relationship between police and public, they have shown limited interest in individual complaints. Lüdtke, Funk and Spencer are mainly concerned with how individual complaints reflect aspects of police violence and how the police authorities dealt with such incidents ${ }^{9}$. Jessen mentions complaints only in relation to those who went to court to challenge punishments issued by the police for minor breaches of Polizeirecht but he does not look at informal complaints to the police authorities ${ }^{10}$. This may be due to lack of material for the Westphalian region, while in Berlin complaints letters for the period 1892-1914 are abundant. In addition to the individual complaints, the records from the Ministry of Justice provide data on individual court cases against members of the Schutzmannschaft. Unfortunately this offers only the most basic data of name, alleged offence, and outcome of the court case ${ }^{11}$.

In terms of access for citizens to complain or hold erring policemen to account, the Prussian procedures were far less open and responsive than the procedures that had been introduced for the London Metropolitan police in the early 1830s and subsequently extended to police forces around England and Wales. Yet, the apparent futility of complaining against the Schutzmannschaft did not deter Berliners from voicing their discontent through the courts, through letters to the Police President (Polizeipräsident) and through the press. In order to understand the thriving complaints culture of Wilhelmine Berlin, this article compares the Prussian complaints procedures to the English system. It then analyses who complained to the Police President, what people complained about, and with what result, in order to identify what Berliners achieved by voicing their grievances.

This article derives from a wider research project into the police complaints in Berlin, Paris and London 1870-1914, comparing the dynamics between police and population within three different regimes and political cultures. Capitals are interesting because they were directly under the control of government authorities and reflect most clearly the difficult balancing act required of governments between maintaining control while being responsive to citizens' concerns. The article is concerned with comparative governance in Berlin and London where policing was politically more sensitive than elsewhere in Germany or Britain, and where the police forces were directly subjected to government control. The regional variations of German and English police-public relations within the context of municipal police forces and local government are not the concern here, but would benefit from some research.

9 Lüdtke (1982, pp. 151-152, 156, 201-202); Funk (1986, pp. 278-296); Spencer (1992, pp. 84-85, 105-107).

10 Jessen (1991, pp. 258-261).

11 GStA, H.A.1, Rep. 84a, microfiche 6740 'Justitsministerium', No., 8264 , Verbrechen und Vergehen im Amte, 1872-1934' Bd. 5 ; ibid., H.A.1, Rep. 84a, microfiche 6746, No. 8265, ,Zusammenstellungen und Nachweisungen über Verurteilungen, Freisprechungen bzw. Begnadigungen von Polizeibeamten wegen Überschreitung ihrer Amtsbefügnisse, 1896-1906'. 


\section{POLICE AND CONTESTING CITIZENS: VENUES FOR COMPLAINTS}

During the Wilhelmine era, the numbers of Berliners who complained against the police increased dramatically. Berliners employed three venues for voicing their discontent: where appropriate pursuing the police through the courts (civil, criminal or administrative); sending a letter of complaint to the Police President; and using the press to make the complaint public. Indeed towards the end of the $19^{\text {th }}$ century, criticism of the Berlin Schutzmannschaft and municipal police forces became a recurrent theme, not only in the Left Liberal and the Social Democratic press, but also in the conservative leaning sections of the press. Even among the peace-loving, law-abiding and loyal citizens the Schutzmänner were, and remained, "the best hated profession of all" as one sympathetic observer put it in $1914^{12}$. Whether this increase in complaints reflects an actual increase in police malpractice, as Funk maintains, or an increasing intolerance towards arbitrary and violent acts by law enforcers is impossible to establish. However as Jessen rightly points out, a change of popular attitudes towards police malpractice becomes noticeable during the $1890 \mathrm{~s}^{13}$.

It has been commonplace among contemporary observers and historians to see the roots of the barking, bossing, impolite behaviour of the Schutzmann as the logical extension of his military background and training. However, as Jessen rightly points out, most serious malpractice occurred in the local branches of the Schutzmannschaft which, during the rapid expansion of the $1890 \mathrm{~s}$, had recruited large numbers of men with no military background. Indeed Jessen points to a "double crisis of legitimisation" which was particularly acute for recruits from unskilled working class milieus with no military background. They had to enforce the law against people who were often better paid, better educated, and socially superior to themselves ${ }^{14}$.

The increasing gap between the extended powers of the Schutzmann and the proletarisation of the profession exacerbated an already conflict-ridden relationship with groups and individuals from all sections of society. The challenges from the public thus reflect the widening gap between the expectations of the police from broad sections of society, and what contemporary observers referred to as the increased 'sense of due rights' (Rechtsbewusstsein) ${ }^{15}$. At the same time, the rigid rejection of citizens' concerns by the police authorities stood in a strange contradiction to the attempts by the Schutzmannschaft to develop elements of public relations through the Berlin Pressebureau and to increase the popularity of the Schutzmannschaft among the Berlin population ${ }^{16}$.

So when conflicts arose, what were the options available to the potential complainant? The Prussian State was notoriously jealous of any intrusion into the uninhibited sphere of action of its law-enforcement agents, and before 1848 had

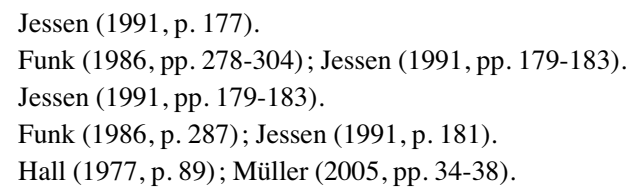


made few concessions were made to allow individuals to challenge police decisions ${ }^{17}$. The majority of the achievements and initiatives passed in 1848 to strengthen the position of individuals against the State were abolished during the subsequent reaction. Although the principles of the Rechtsstaat was gradually established from the 1860s whereby policing had to take place within clearly defined legal boundaries, it remained notoriously difficult to take action successfully against individual policemen and obtain recognition of guilt or wrongdoing.

According to the principle of the Rechtsstaat, administrative courts were in charge of testing the legality of decisions made by public authorities - including the police - and within the Schutzmannschaft strict rules maintained discipline. However, unless breach of law or disciplinary regulations could be demonstrated, no fault existed. Questions of appropriateness or proportionality of police actions did not come into consideration ${ }^{18}$. Aggrieved members of the public had three officially recognised outlets to challenge the police: (a) for incidents where individual policemen were alleged to have acted outside the law, criminal prosecution in court was a theoretical - if rarely an effective - option; (b) the legality of administrative decisions by the police could be challenged in the administrative courts; (c) and finally there was the possibility of addressing an informal complaint (Beschwerde) to the most senior police authority: in Prussian provinces this was the state-appointed governor at local, district or province level, in Berlin it was the Police President ${ }^{19}$.

Due to the restricted venues for complaints and the ineffective procedures for parliamentary control of the Schutzmannschaft, German Liberal critics pointed to the political and judicial mechanisms which existed in Britain to counterweight police powers and to guarantee respect of civil liberties. In the light of the extreme unpopularity of the Schutzmann even senior officials within the Prussian civil service looked to the English bobby as a model to be copied ${ }^{20}$. Demands for policing within the boundaries of the law and for reform of the police along the lines of the English Bobby, which were prominently on the liberal agenda in the 1860s and 1870 s, re-emerged in the bourgeois press, occasionally extending to the conservative press and those very groups who otherwise saw themselves as staunch supporters of the regime ${ }^{21}$.

To be sure, the image of the polite English bobby was to a large extent a construction covering an often darker side of the policing of the poor ${ }^{22}$, and the process of complaining against the English police was not without difficulties ${ }^{23}$. Yet the Londoners' ability to complain to the Commissioner and ultimately to the courts had

17 Law on the extent of legal action in relation to police decisions (1842); Organisation of administrative courts (1870s); Law on the administration of local communities (1883) Chapter 4, articles 127 133. See also Funk (1986).

18 Johansen (2007); Jessen (1991, pp. 218-219).

19 Law of 30 July 1883, "Gesetz über die allgemeine Landesverwaltung”, Title 4, Articles 127-133.

20 Segger (1898, pp. 33-40); Lemke (1904, pp. 209-211).

21 Funk (1986, p. 276); Emsley (2004, p. 199).

22 Miller (1973, pp.138-139); Robert D. Storch (1975); Emsley (1996, pp. 61, 68-69); Emsley (2003, p. 195); Taylor (2002, pp. 89-92).

23 Emsley (1996 p. 66). Similarly the Royal Commission of 1908 was described by one commentator as a whitewash of the police, with the author deploring the lack of effective complaint procedures. See also L. A. Atherley-Jones Letter to the Editor 'The Police Commission', The Times, 11 August 1908. 
been a central element in the political compromise that allowed a police force to be organised. Indeed since the early days of the Metropolitan police, the first Commissioners, Rowan and Mayne, actively encouraged members of the public to report poor behaviour among constables. Citizens' complaints were used as an effective managerial tool to maintain discipline within the force, but this also had important additional advantage. In the first place, inviting citizens to voice their concerns helped to strengthen the legitimacy of policing. Moreover it reassured the London public - notably sceptical middle-class voters - that legal and institutional limitations existed around the use of police force and that robust control mechanisms legal, managerial as well as political - safeguarded the law-abiding citizens against police violation of their rights.

\section{THE POLITICAL CONTEXT: PARLIAMENTARY CONTROL AND PUBLIC ACCOUNTABILITY}

Another obvious difference with the Metropolitan police was the Schutzmannschaft's lack of parliamentary accountability. German parliamentarians had no direct means of holding the interior minister to account or forcing the Police President to discipline erring policemen. On the other hand, Prussian-German government authorities could not prevent deputies from raising questions on policing issues, and this happened repeatedly both in the Reichstag and the Prussian Diet. The Reichstag was not an ideal forum for such debates as it was only the Reich interior minister who appeared before this assembly, and he could legitimately refuse any responsibility for the actions of the Schutzmannschaft as this force was responsible to the Prussian interior minister. The Prussian Diet was therefore key to any debate on the Schutzmannschaft and police malpractice. The Prussian interior minister appeared regularly before this assembly and, even if he was not politically accountable, he could be pressed to answer questions when challenged by deputies, particularly when he needed the Diet to approve proposed budgets ${ }^{24}$. That said, the Prussian Diet was unlikely seriously to challenge the police or exercise any effective control since the income-based three class voting system gave the government a solid majority in both chambers.

If police actions in the street earned the Berlin Schutzmannschaft a reputation for being out of control, this was only exacerbated by successive interior ministers who arrogantly dismissed any concern about police malpractice and repeatedly backed the Police President's justifications of heavy-handed police interventions. There would be no resignation or sacking of senior police officers as this would amount to an implicit recognition of limits to the activities of the police, which the PrussianGerman system was extremely reluctant to provide. The systematic refusal to admit any wrongdoing created the impression that the Prussian authorities were unrepentant in their justification of any level of brutality and inflexible towards any public

24 Between 1898 and 1914 the issue of police malpractice was repeatedly raised both in the Prussian Diet $(17.2 .1898 ; 17.2 .1899 ; 5.2 .1903 ; 31.1 .1908 ; 23.2 .1910)$ and in the Reichstag $(22.11 .1902$ about ill-treatment in police stations; 11.3.1910 about the police intervention in the Tiergarten and Treptower Park and in December 1910 following the clashes between police and workers in the working class area of Moabit). 
criticism and concern. One notable example of this occurred during the debate following the police intervention in March 1910 against Social Democratic demonstrators and unsuspecting visitors to the Tiergarten. The justifications provided by the Prussian Interior Minister Delbrück on behalf of Police President von Jagow were fanciful in the extreme, using the legislation in a highly creative fashion to argue that the police behaved technically within the boundaries of the law ${ }^{25}$.

What distinguishes the German debates on police malpractice from similar parliamentary debates in London is the fact that the Prussian-German authorities did not feel the need to deny or even to conceal that disproportionate physical force had been used. In the face of what appeared to be irrefutable evidence of illegality, brutality or malpractice, the authorities defended the police actions as legal, legitimate and necessary. The poor justifications and the blatantly disproportionate violence could only have the effect of strengthening the impression that the police were out of control and even resourceful citizens could only draw the conclusion that they were unlikely to get a fair process in any conflict with the police. This intransigent position increasingly backfired as the Social Democratic deputies in the Prussian Diet and the Reichstag repeatedly placed the issue of police malpractice on the political agenda and used the legislative assemblies as a platform for publicly shaming the police. Even people who had no sympathy for the Social Democrats - or who were otherwise staunch defenders of law and order - sometimes recognised that the actions of the police were indefensible and that the justifications provided by police authorities were hollow and unconvincing ${ }^{26}$. Although the Social Democratic criticism had no immediate impact, in the long term it meant that the police gradually lost the moral argument.

In London police accountability to Parliament, like the complaints procedure, was an instrument that served both to ensure popular acceptance of police and to strengthen legitimacy, but it was under careful control. As the only force that was directly answerable to the Home Office, it was possible for MPs to challenge the home secretary on issues relating to the London Metropolitan police. Of course, there were limits to the effectiveness of this accountability to Parliament: general issues of standards, of discipline and police tactics could easily be brushed aside as the Home Secretary could refer to this as the responsibility of individual police forces or the operational freedom of the chief constable. However, it occasionally happened that individual cases of alleged misconduct raised in Parliament, placed the Home Secretary and government seriously on the defensive, and led to government defeat in Parliament, to a parliamentary inquiry and even to the resignation of the Commissioner ${ }^{27}$.

On the one hand, through the apparent responsiveness to citizens' concerns the legitimacy of the police was strengthened. On the other hand, however, there were plenty of mechanisms within the procedures, which helped to steer the investigation

\footnotetext{
25 Minutes from the debate in the Reichstag, 11 March 1910, pp. 1981-1985.

26 The huge collection of press cuttings by the Central-Bureau of the Interior Ministry reflects the unease about the police across the political spectrum excluding the conservative press and the far right (GStA, HA1, Rep. 77, CB S, No. 48, vol. 4 ; No. 425 vols.1-2; No. 861 3-5; No. 864 vols. 1-2).

27 Chief Commissioner Edmund Henderson resigned after the 1886 riots at Trafalgar Square and Charles Warren was allowed to resign after two very controversial years as Chief Commissioner. See Emsley (1996, pp. 66-67); see also Taylor (1997, p. 103) on complaints against the enforcement of the Contagious Diseases Acts 1883-1886.
} 
in such ways as to avoid revelation of embarrassing errors or scrutiny into possible systemic malfunctions. Thus through careful definition of the object and scope of investigations, embarrassment or damage to the police organisations was carefully contained by focusing on a few "rotten apples" who could then be disciplined or sacked. By allowing some controlled admission of individual error, embarrassing incidents of malpractice could - if successfully managed - turn into a showcase of how the police was capable and willing to identify and root-out erring policemen, as happened during the Royal Commission of 1906-1908. The moral high-ground was maintained and the Metropolitan police came out with its legitimacy strengthened.

\section{TAKING A CASE TO COURT}

As political mechanisms for holding the Berlin Schutzmannschaft to account were weak, the main external control of the police was through the courts; the administrative courts tried the legality of decisions made by police authorities while the criminal courts handled allegations of breach of the criminal code by individual policemen. Yet, it was extremely difficult to win a criminal case against a Schutzmann. To be sure, the English system also developed some institutional and procedural mechanisms which effectively limited access to justice when the accused was member of a police force. Even within the English system it could be difficult to prove that a policeman had acted in violation of his legal authority, particularly since the policeman's version of events was often supported by statements from other policemen ${ }^{28}$. Moreover, legal proceedings against policemen were characterised by a hierarchy of credibility where witnesses' accounts were treated as suspicious, while the policeman was assumed to speak the truth at least until the opposite was proven. In addition there was some degree of magistrates' bias against members of the lower orders ${ }^{29}$.

Similar biases in favour of the police existed in Germany, particularly in Prussia where some additional features of the criminal justice procedures made it even more difficult to seek redress through the courts. Whereas the English jury system occasionally let to the conviction of policemen against the wishes of judges and magis$\operatorname{trates}^{30}$, there were few elements within the Prussian criminal justice system that could counter-balance the bias in favour of the police. The courts were a branch of the State like the police and both the public prosecutor and the judge were state officials. Very serious crimes such as murder and manslaughter would be tried before a Schwurgericht with twelve lay jurors, however there were severe restrictions on who could act as juror and their influence was limited to determining guilt or innocence. Unlike the English system where any member of the public could bring a case before the court, Prussian victims would have to persuade the public prosecutor that the policeman in question had acted in violation with his legal entitlement. The majority of attempts to prosecute Schutzmen for manslaughter or grievous bodily

28 HMSO, Royal Commission upon the Duties of the Metropolitan Police (1908) Part III 'Conclusions and Recommendations' Vol. 1., pp. 105-106 \& Witness statement of 4 June 1907 from Sir M.D. Chalmers, Vol. III, pp. 1109-1110, paragraphs 47690-47696.

29 Emsley (1996, pp. 66, 79, 94).

30 Emsley (1985, pp. 126-129, 141-142). 
harm never reached the courts because the public prosecutor considered that wounds and other injuries had not been inflicted by the policeman. As a consequence, only cases where irrefutable evidence of illegality on the part of the policeman could be established had a chance of getting to court.

The key factor that made prosecution of policemen particularly difficult in the Prussian system was the nature of the law. Police forces, like any other public authority of Wilhelmine Germany, were committed to operate within the strict boundaries of the law. However, if the principles of the Rechtsstaat inspired the official rhetoric, practice as well as the implicit rationale in internal police memos and instructions followed a late-absolutist notion that any opposition to a public authority legitimised unrestricted use of force ${ }^{31}$. Courts dealt only with the question whether the policeman had overstepped his legal entitlements in technical terms, and unlike the English courts did not make judgements about the appropriateness or proportionality of the act. In practice it was almost impossible to prove that the policeman had acted illegally as the boundaries around police actions were extremely elastic. Moreover the Prussian legislation on policing was formulated in terms of what the police was positively allowed to do, but vague on the limitations around police powers ${ }^{32}$. Even in cases where the public prosecutor recognised that grievous bodily harm might indeed have been inflicted by a Schutzmann and criminal procedures were opened, it was easy for the defence to find some law or regulation that authorised the Schutzmanm to use force and thus place him within the boundaries of the law.

Moreover, the position of the complainant was easily weakened or undermined. The myriads of laws and police regulations provided multiple opportunities to argue that a complainant had in fact been technically in breach of some law or police regulation, thus justifying the police intervention. Arguments such as the person had not been aware of breaching a police ban on being at a particular place at a particular time was no excuse. For instance, if police authorities issued a formal ban on an assembly it gave the police legal authority to use force against whoever happened to be in the area. The policeman could also easily develop an argument about the supposed victim having resisted police by not moving quickly enough when told to do so.

Similar justifications were used by London Metropolitan constables whenever accused of brutality. However in the English system, the accused policeman would also need to explain why the level of force used was necessary and proportionate. The Prussian Schutzmann did not need to be concerned about that. Although Prussian police manuals all stressed the importance of a polite and open attitude towards the public ${ }^{33}$, it was also made quite clear in the instructions to the police that people who were in breach of the law should be dealt with in the harshest possible terms. Indeed, the recommendation given in the service regulations and the police manual was to use force, including weapons, in measures that would leave no doubt about the superior strength of the police and their readiness to act $^{34}$. Almost any form of

\footnotetext{
31 Gerland (1895, section iv); Eiben (1903, p. v). Similarly Funk (1986, p. 183).

32 Johansen (2007).

33 Dienstanweisung für die Schutzmänner des königlichen Polizei-Präsidiums zu Königsberg in Preussen. Vom 28 Juni 1887 nebst den später ergangenen Zusätzen (1902) GStA, H.A.1, Rep. 77, Titel 1190, Nr., 2, Vol. 2; Segger (1898, p. 40); Eiben (1903, v-viii); Bartels (1909, p. 11).

34 Dienstanweisung...(1902); Gerland (1892, part 4 section 20) on the use of weapons; Eiben (1903, p. viii); Geyger (1909, pp. 19-47); Bartels (1913, pp. 13-14).
} 
violence could therefore be justified by referring to the illegal position of the complainant. Accordingly, it was almost impossible to demonstrate that police use of force - no matter how disproportionate - had been technically outside the limits of what the police was legally authorised to do.

Despite these difficulties, some members of the Schutzmannschaft were convicted for having transgressed their legal authority (Überschreitung ihrer Amtsbefügnisse). Between 1899 and 1905, 556 cases were brought before the Prussian provincial courts (Landgerichte), for beaches of the paragraphs 339-343 of the Penal Code; these were mainly cases of causing grievous bodily harm or manslaughter in the course of duty. As many as 400 of these cases resulted in conviction $^{35}$. This might seem an extremely high conviction rate, particularly given the inherent difficulties of bringing a criminal case against a Schutzmann. However, as most of the investigations and interrogations were conducted before the trial, only the cases that were likely to lead to conviction were ever brought before court. With conviction rates for all serious offences being above 80 per cent throughout the period $1882-1927^{36}$, the conviction rate for policemen at 72 per cent was still significantly lower than for ordinary criminals. The offences for which these Schutzmen were tried could lead to a maximum of four years of imprisonment, yet the policemen who were convicted all received penalties which fell far short of four years. More than half (209) were given fines only, while among the 191 who received jail sentences 173 got six months or less. Only two got more than two years. Out of the 400 convicted Schutzmen 271 subsequently appealed to the Justice Ministry to have their sentence reduced by royal intervention, and this was granted in almost 50 per cent of the cases ${ }^{37}$. Most importantly a conviction for violence in Germany was no hindrance for returning to the Schutzmannschaft $t^{38}$. In England a conviction for brutality normally led to the policeman being dismissed from the force ${ }^{39}$.

The criminal cases constituted only a tiny part of the legal challenges to the police. The major bulk were those brought before the administrative courts to settle disputes over administrative decisions by the police authorities. Although the principle that decisions of public authorities could be tested in court was well established in German legal tradition since the eighteenth century, it was only during the 1870s that individual German states introduced administrative courts according to the French Napoleonic model ${ }^{40}$. The ordinary civilian courts remained the first

35 Figures from the Prussian Ministry of Justice, GStA, H.A.1, Rep. 84a, microfiche 6740 'Justitsministerium', No., 8264 ,Verbrechen und Vergehen im Amte, 1872-1934' Bd. 5; ibid., H.A.1, Rep. 84a, microfiche 6746, No. 8265, 'Zusammenstellungen und Nachweisungen über Verurteilungen, Freisprechungen bzw. Begnadigungen von Polizeibeamten wegen Überschreitung ihrer Amtsbefügnisse, 1896-1906'. Similarly Funk (1986, pp. 285-287).

36 Figures based on Johnson (1995, p. 123).

37 GStA, H.A.1, Rep. 84a, microfiche 6746, 'Justitsministerium' No. 8265, 'Zusammenstellungen...'

38 Although Lemke (1904, p. 209) claims that conviction for malpractice often led to dismissal from the police, it is clear from the records from the Justice ministry that many of the policemen seeking reduction of their sentence had previous convictions. GStA, H.A.1, Rep. 84a, mf. 6746, 'Justitsministerium' No. 8265, 'Zusammenstellungen...'.

39 The Metropolitan Police Act of 19 June 1829, Art. 5 on suspension and dismissal. See also Howard (1883, p. 13).

40 The Southwestern Kingdom of Baden was the first to introduce administrative courts in 1863, followed by Prussia, Hesse, Wurtemberg and Bavaria in the years 1872-1878. 
instance for administrative disputes ${ }^{41}$, but the establishment of higher administrative courts provided specialised knowledge on public law and created a greater measure of consistency in the settlement of disputes between individual citizens and public authorities. The main limitation on the administrative courts was that their judgements were purely technical, namely to test the legality of administrative decisions, to determine the limits of laws and to settle correct procedures in public administration. The administrative courts were not supposed to judge the necessity or appropriateness in the decisions of the police authorities ${ }^{42}$.

The effectiveness of the administrative courts in redressing the inherent imbalance in the power relationship between citizens and police authorities was therefore limited. The disputes which were settled through the administrative procedures concerned primarily the rights of property-owners and people running businesses, from small retailers, craftsmen and publicans to great industrialists. People with low income would rarely take measures against administrative decisions made by the police as it was expensive to bring cases before the administrative courts. Moreover the conflicts appearing before the administrative courts mainly concerned disputes between property-owners and police authorities. The conflicts which were most common between police and the lower orders of society (harassment, arbitrary detention, violence), in contrast, were not the object of administrative proceedings. The limitations placed on the police by the Supreme Administrative Court (Oberverwaltungsgericht) were vague and their decisions could be overridden easily by reference to the superior principle of the defence of the interests of the State ${ }^{43}$. In a wider sense, however, the existence of administrative courts was important as they provided the most unambiguous recognition by individual German states that citizens had the right to challenge the police, at least on legal technicalities.

\section{COMPLAINING TO THE POLICE PRESIDENT AND THE INTERNAL POLICE INVESTIGATION PROCEDURES}

The limited likelihood of getting any legal redress in conflicts with the Berlin Schutzmannschaft provides interesting evidence of the resilience and resistence of the supposedly submissive Germans. The 1883 Law on Public Administration regulated policing and defined the citizens' ability to challenge the police by launching a Klage or a Beschwerde ${ }^{44}$. The Klage was a challenge to the legality of an administrative decision and was processed through the administrative courts; the Beschwerde was an informal complaint addressed to the most senior police authorities and handled through internal police investigations. The informal Beschwerde was free of charge and it was open to a broader range of issues than the Klage.

Partly as a result of its limited remit and considerable costs, the Klage to the administrative courts was the preserve of the propertied classes, while the Beschwerde procedures were used by people of all creeds and conditions. The significant

\footnotetext{
41 Law of 30 July 1883 Über die allgemeine Landesverwaltung, Article 127.

$42 \operatorname{Kampf}(1894$, p. 71).

43 Funk (1986, p. 183).

44 Law of 30 Juli 1883, Title 4 'Rechtsmittel gegen polizeiliche Verfügungen', Articles 127-133.
} 
increase in the number of informal complaints to the Police President during the 1890s took place despite extremely scarce information about the complaints procedures. In addition one needed some level of education to understand the complex legal formalities that had to be observed when making a complaint. These effectively placed important restrictions: the complaint had to be in writing, sent no less than five days after the incident in question, and the complaint had to come from the victim of the alleged police error or misconduct. No complaint on behalf of a third party would be accepted, except through a lawyer, and people who repeatedly brought complaints on behalf of others could be penalised with fines and ultimately with prison ${ }^{45}$.

The correct way to complain was to approach to the Landrat or burgomaster in rural areas or towns with municipal police and in Berlin to the Police President. Occasionally complaints were addressed to the interior minister, who forwarded them to the Police President's office as a matter of routine. The extent to which people turned up to make a complaint in person at local police stations is impossible to assess as no documentation at this level seems to have survived. This course of action was sanctioned by a law of $1842^{46}$ and by the end of the nineteenth century such immediate approaches may still have been accepted, but Bernhard von Kampf did not mention the procedure in 1894 and, in any case, there was no formal obligation on the part of the police to investigate such oral complaints.

If there were strict rules about how citizens were to proceed in making a complaint, there were no formal rules about how that complaint was to be processed by the police authorities. Instead a set of standard procedures developed within the police. These procedures for handling complaints stacked the odds even more against the complainant than the investigative procedures followed by the courts. Once the Police President received a complaint, he would send it to the police station of the Schutzmann in question. The head of the police station would then take statements from the policeman concerned as well as from other policemen who might have witnessed the incident. Not surprisingly these statements invariably supported the version of events provided by the accused policeman, no matter how outlandish or fanciful these might be. In most cases no other witnesses were called even where the complainant produced names and addresses of independent witnesses - and only occasionally did the investigations include a statement from the complainant. As it was not only the individual Schutzmann, but also his immediate superior who had an interest in concealing any trace of malpractice or mismanagement within the unit it is hardly surprising that the investigations invariably led to the conclusion "after thorough investigation" that the policeman had no case to answer. The head of the local police station sent his conclusion to the Police President who generally rubber-stamped it as a correct handling of the situation by the police.

45 This was first stipulated by law in Allgemeine Bestimmungen. Anordnungen Betreff der bei dem Könige oder den Ministerien anzubringenden Beschwerde of 14 Feb. 1810 art. 4-6 (Preussische Gesetzsammlung, No. 1 1806-1810, pp. 641-643). All later legislation assumes that the complaint is presented in writing, by the aggrieved person or the head of the household to which he or she belonged.

46 Law of 11 May 1842 Gesetz über die Zulässigkeit des Rechtsweges in Beziehung auf polizeiliche Verfügungen. According to this law, any question concerning the legality, the necessity or the purpose of any police action were to be addressed to the immediate superior (vorgesetzte Dienstbehörde). 
Complainants faced other problems also. The Police President was under no formal obligation to respond to a letter of complaint. Some complainants received a brief letter from the police at the end of investigations, but often these letters were sent after the complainant had written to the police asking to know how their complaint was progressing. Formal apologies did not belong to the vocabulary of the Schutzmannschaft probably because any acceptance of fault would amount to recognition of limits on the activities of the police as a corps. Only occasionally can one sense a flicker of admission that, perhaps, the policeman could have handled the situation better, and this only happened when the complainant was in a very strong social position ${ }^{47}$.

Investigations into complaints occasionally led to disciplinary procedures, but the complainant would not be informed as this was regarded as a strictly internal personnel matter. The issues that could lead to disciplinary investigations were generally not the main object of the original complaint and only marginally relevant to the concerns of any ordinary member of the public. Typical reasons for disciplinary action ranged from minor breaches such as a missing button on the uniform and shabby appearance, to major offences such as drunkenness or non-attendance on duty, non-intervention against law-breaking, non-compliance with orders, corruption or dishonourable conduct on or off duty. Whether impolite or heavy-handed behaviour towards members of the public constituted a breach of discipline was a matter of judgement for the superior of the accused Schutzmann ${ }^{48}$.

With all their limitations, the Prussian complaints procedures nevertheless shared some features with the English system. Complaint letters to the watch committees and, in London, to the Commissioner of the Metropolitan police led to internal police investigations with procedures very much resembling those in Prussia. While the watch committees were supposed to provide independent external oversight in the handling of complaints, even the Home Office was very lax in its obligations to oversee internal police investigations into complaints against the Metropolitan police, and this became clear during the Royal Inquiry of $1908^{49}$.

The difference between the handling of complaints in London and Berlin did not lie so much in the legal and procedural details as in the application of these procedures, particularly when the complainant belonged to the 'respectable' classes. In both systems it was clearly understood that the ability to complain was primarily intended for members of the 'respectable' classes. Yet the London middle classes had much more reason to be confident than their Berlin counterparts that they were capable of taking on the police, and winning. Successive police commissioners were aware that they could not afford to antagonise the 'respectable' classes and much was done to reassure the middle classes that the police were not intended to operate as an unaccountable strong arm of the executive. The 'Bobby' was essentially a servant to be hired and fired by the politically accountable Home Secretary and outside London by the elected representatives on local watch committees ${ }^{50}$. Indeed, watch

47 BLA, A. Pr. Br. Rep. 030, Titel 94, No. 8880: Beschwerden wider Polizeibeamten, 1911-1912 (document 396) letter of 16 September 1912 from the Interior Ministry to Herr Georg Reinwald, Factory owner and merchant.

48 Funk, 1986b, p. 294.

49 HMSO, Royal Commission upon the Duties of the Metropolitan Police (1908) Witness statement of 4 June 1907 from Sir M.D. Chalmers, Vol. III, pp. 1109-1110, paragraphs 47690-47696.

50 Taylor (2002, pp. 92-93). 
committees and successive police commissioners in London could, and did, dismiss constables or reduce their rank on discretionary basis as simple personnel matters.

The Berlin Schutzmann could be disciplined or dismissed on the basis of disciplinary failings, but there seems to be a great reluctance to allow citizens' complaints to count as reasonable grounds for disciplinary action. This would have upset the fundamental balance of power between agents of public authority and ordinary citizens: even members of the 'respectable' classes were to obey the instructions of any policeman as enforcer of the Law and police was not accountable to them as taxpayers or voters. As a result, even members of the Berlin bourgeoisie could not be confident that any notice would be taken of their complaints.

\section{SUBMISSIVE GERMANS? WHO COMPLAINED AND WHY}

Despite these shortcomings and the very limited scope for any tangible outcome, Berliners complained in their hundreds. The complaints filed in the Police President's office probably only constitute the tip of the iceberg as these were the complaints that fulfilled the restrictive formal requirements. We must assume that an important number of complaints were rejected on the basis of not conforming to the restricted time limit, the written format for complaining or were addressed on behalf of a third person. Indeed, many of the allegations of police brutality which appeared in the press, notably the Social Democratic press, do not appear as complaints to the police authorities.

The complaints addressed to the Berlin Police President by aggrieved members of the public between 1890 and 1914 came from across the entire social spectrum, and not simply from the 'respectable' classes. The numerous complaints from members of the lower orders challenge Funk's observation for the more extended period of 1848 to 1914 that only members of the middle and upper rungs of the social hierarchy addressed complaints to the police prefect ${ }^{51}$. For the period 1892 to 1913, about half of the complaints came from people who had few resources in terms of money, connections or even the ability to write a formal letter; they included a man who ran a lottery-ticket booth and an elderly female street vendor of newspapers ${ }^{52}$.

It is also worth noting that a substantial number of complainants were women ${ }^{53}$. The complaints from members of the lower orders were generally written by the aggrieved person him- or herself, unlike in England where members of the 'respectable classes' often complained on behalf of a third person, in particular criticising the ways in which police handled members of the lower orders ${ }^{54}$. Occasion-

51 Funk admits looking only briefly into the complaints directed to the Berlin Police President and concluded that workers and members of the lower orders did not use this venue for complaint. Funk (1986, footnote 650).

52 BLA, A. Pr. Br. Rep. 030, Title 94, No. 8872, documents 132-135; ibid., No. 8881, documents 41-59.

53 Female complainants tended to complain over similar issues as their male counterpart. The one complaint concerning a woman who had been erroneously taken to be prostitute were written by her husband (BLA, A. Pr. Br. Rep. 030, Title 94, No. 8881, document 95-99: Otto Hintze, 23 Januar 1913.)

54 Emsley (1996, pp. 68-69); Taylor (2002, pp. 93-94). 
ally Berlin employers' complained about the treatment of their employees by the police, but only when the conflict with the police occurred in the course of the employees' professional duties ${ }^{55}$. What happened to employees outside their workplace was not something that their employer could complain about legitimately.

Not surprisingly, workers and the urban poor stood little chance of getting redress from any unjust, brutal or arbitrary police action by writing to the Police President, but citizens with considerable social capital were equally unlikely to be successful. Even so, people from all social backgrounds took the pains to complaint despite the risks of attracting police attention and subsequent police harassment. And the complaints, including those from people with limited social capital, show that people were aware of their basic rights and had some notion that there were boundaries, defined by law that determined what policemen were entitled to $\mathrm{do}^{56}$. Moreover, many knew enough about the complaints procedures to get the formalities right despite the scarcity of public information.

Most complaints concerned petty conflicts with the local Schutzmann including allegations of police corruption and favouritism, or police harassment. Typically shopkeepers and businessmen complained, individually or collectively, that police obstructed them in the exercise of their profession either through unjustified enforcement of petty regulations or harassment by targeting certain shops, restaurants and pubs with overzealous interference, fines and unreasonable demands ${ }^{57}$. While members of the lower orders often explicitly demanded that policemen treat them with dignity irrespective of background or social position ${ }^{58}$, only a few of the complaints contain elements of criticism against the political regime and the social order. Occasionally the tone in the complaints letters is self-assertive, but mostly it is deferential even when expressing indignation. Nevertheless, one should not mistake the deferential tone for submissiveness. The overly polite - sometimes even apologetic - use of language was necessary in order to appear righteous and reasonable, and above all to anticipate any accusation of Social Democratic sympathies. This may explain why a great many complainants strongly insist on their lack of sympathy or connections with the Social Democrats while declaring their loyalty to the King and Kaiser.

Very few among the complainants seem to have had obvious connections with the Social Democratic Party. However it was not uncommon for complainants to threaten the police authorities that they would reveal their story to the Social Demo-

55 BLA, A. Pr. Br. Rep. 030, Title 94, No. 8880 (documents 1-7) December 1911; ibid. (documents 345-396) April-September 1912. Berlin Landesarchiv, A. Pr. Br. Rep. 030, Title 94, No. 8881 (documents 155-157) December 1912.

56 BLA, A. Pr. Br. Rep. 030, Title 94, No. 8872 (document 70): Press cut from Vorwärts, 30 Juli 1892; GStA, H.A.1, Rep. 90 A., Staatsministerium, Jüngere Registratur, No. 3783 (document 101): Press cut from Norddeutsche Allgemeine Zeitung, 8 March 1910; Similarly Eiben (1903, p. Viii); Lemke (1904, pp. 202-203).

57 BLA, A. Pr. Br. Rep. 030, Title 94, No. 8881 (documents 18-29) Complaint of 7 October 1912 from Firma Elken \& Co. against the local Schutzmanns; ibid. (documents 30-32): Complaints from a group of pub owners (Schrankwirte) claiming to have their business undermined by zealous police interference against their customers.

58 Lindenberger observes that the lower orders of the Berlin in their challenge of public authorities in the streets operated within a set of norms that demanded equal treatments by the authorities and rejected the violent approach by the police as an attack on their "honour". Lindenberger (1995, pp. 395-397). 
cratic press if the authorities failed to discipline the Schutzmann in question. Indeed, the Social Democrats played a crucial role by providing an alternative venue for airing people's grievances: they supported some complainants and, most importantly, they disseminated information about complaints procedures and showed how police could be put on the defence. Since its legalisation in 1890 the Social Democratic Party consistently challenged the police by raising embarrassing cases of police malpractice. Occasionally Social Democrats sent complaints to the Police President, to the interior minister, and to other relevant authorities, demanding explanations. Here the tone was anything but deferential: open confrontation, sarcasm or mockery was the speciality of the Social Democrats who knew from the outset that they would get nowhere in appealing to the reason and sense of justice of the public authorities, least of all the police.

Yet, occasionally, such complaints forced the authorities on to the defensive. If no satisfactory answer was provided, the Social Democrats returned to the complaint and followed it up, printing the answers and non-answers in the press like an ongoing soap-opera ${ }^{59}$. Given that the explanations provided by the police authorities were often unconvincing in their justification of 'correct' police behaviour, this had the effect of making the police authorities look untrustworthy, silly and above all weakening police legitimacy in the eyes of the wider public ${ }^{60}$. Thus the closed and unresponsive police system came under spotlight with the Social Democrats adopting a policy of naming and shaming in the event of police malpractice. The awareness and practical knowledge about complaints procedures generated through such campaigns go a long way towards explaining the upsurge in complaints from the 1890 s onwards.

\section{FALLING OUT OF LOVE WITH THE POLICE: THE BOURGEOIS COMPLAINTS}

In Germany as in most other parts of Europe, the bulk of the propertied classes generally supported the police as the first line defence against crime and popular unrest $^{61}$. While German Liberals of the 1860s had pressed for increased control of police and called for reforms along the lines of the English police, any attempt at liberalisation was abandoned after the Paris Commune when law and order became the first priority amid fears of imminent social revolution. In the 1870s it was still possible for the Schutzmannschaft to operate as they did during the years of conservative backlash after the 1848 Revolution. Yet by the 1890s an ever greater number of complaints to the police president and the press came from members of the Berlin

59 An early example of this appears in a lengthy case running over the summer of 1892 after a violent intervention by police and mounted gendarmerie against a Social Democratic procession. The man who complained was not a Social Democrat but was caught up as an unsuspecting bystander. Nevertheless, the Social Democratic press used the occasion to publicise the responses from the authorities as a means of shaming the inadequate responses from the police authorities. BLA, A. Pr. Br. Rep. 030, Title 94, No. 8872: 'Beschwerden der Bevölkerung über Polizeidienststellen und Polizeibeamte in Berlin, 1892-1901' (documents 24-75).

${ }^{60}$ Lindenberger $(1995$, p. 397) makes a similar observation about the logic of disciplined street demonstrations.

${ }_{61}$ Funk (1986, pp. 210, 274-278); Emsley (1983, p. 148). 
Bürgertum $^{62}$ indicating the extent to which the relationship between the police and the pillars of Wilhelmine society came under serious strain during the reign of Wilhelm II. The police authorities made repeated attempts to encourage the rankand-file to make a distinction in their treatment of common people and members of the 'respectable classes' (bessere Stände), that is the kind of people that the police management were keen not to antagonise ${ }^{63}$. Nevertheless, the number of bourgeois complaints continued to grow.

Significant in the increased complaints from members of the Berlin Bürgertum were those from industrialists and wealthy businessmen who claimed to have had their professional activities obstructed by interfering policemen ${ }^{64}$. It is, perhaps, not surprising that in contrast to London, there were very few complaints about any police failure to act or interfere ${ }^{65}$. The Prussian police was notorious for its petty and intrusive enforcement of countless rules and regulations. This was not all the fault of the individual policeman, since he was duty-bound to intervene against any breach of the myriad of laws and regulations, irrespective of the social position of the offender. Indeed policemen faced serious consequences if found guilty of non-intervention since this amounted to neglect of duty ${ }^{66}$. Many of the complaints from businessmen and manufacturers concerned incidents where the policeman had enforced perfectly sensible rules for keeping the public streets clear of carriages that blocked the traffic in a city suffering from serious overcrowding. The Schutzmann was in the uncomfortable position of having to tell rich and influential entrepreneurs what they could and could not do in relation to noisy or smelly enterprises in the middle of heavily populated areas or intervene when the public space was used as an extension of private premises for the storage of goods or parking of wagons.

Underlying the conflicts over police interference, there seems to have been a widening gap between bourgeois expectations of police behaviour and the reality. The increased police interference in the activities of business and industry created much consternation from self-assertive members of the bourgeoisie who were not inclined to be told off by a simple policeman. This was not what the propertied classes had in mind in the early 1870 s when they called for better protection, nor had they anticipated that the increased police presence, particularly in the wealthy parts of Berlin city centre, in Chalottenburg and Schöneberg would also lead to much closer scrutiny of their own affairs than had previously been the case. In addition to the thorny issue of lack of control over the police, new concerns emerged, particularly that the Berlin Bürgertum could no longer take for granted that they would be met with a deferential attitude from the ordinary policemen or get the preferential treatment to which they believed themselves entitled.

62 The definition of the German Bürgertum used here is the one described by Kocka, Mitchell (1993, pp. 9-11).

63 In 1892 there are references to an instruction from 1889 by Police President von Richthoffen clearly stating that "Personen der besseren Stände" should not be treated with undue harshness. BLA, A. Pr. Br. Rep. 030, Title 94, No. 8872 (document 11).

64 One great merchant and entrepreneur Georg Reinwald addressed a complaint to the police president covering 23 typewritten pages about the local Schutzmann obstructing his business. Berlin Landesarchiv, A. Pr. Br. Rep. 030, Title 94, No. 8880 (documents 345-396).

65 Miller (1973, pp. 111-116); Weinberger (1981, pp. 76-77); Emsley (1996, pp. 45-46).

66 Jessen (1991, pp. 217-219). 
This new situation was at least in part the result of great-city anonymity. As Berlin developed into city with over two million inhabitants and the Berlin Schutzmannschaft increased from 2,000 men in 1870 to 9,000 men by 1910 , the Bürgertum lost whatever indirect control over policing they had held by virtue of being citizens of note. Earlier in the century, while Berlin still had the character of a small town, policemen would often recognise prominent members of the local community and treat them with respect. This was no longer the case in the metropolis of the Wilhelmine era. Equally, the public no longer knew the identity of policemen except for those who patrolled in the local area. Thus, it is a general feature that complainant and policeman were not personally acquainted. The Berlin Schutzmann carried the number of his unit visibly on his uniform, but unlike his English or French counterpart he did not carry a personal number. Accordingly there were few ways of identifying the individual policeman if he refused to give his name, which he often $\mathrm{did}^{67}$. Again and again a complaint could not be pursued because the complainant was unable to identify the policeman beyond stating, for instance, that he was tall, blond and sported a moustache.

Members of the 'respectable' classes painfully experienced their increasingly defenceless position in encounters with the police. While members of the London middle classes were rarely the object of police violence ${ }^{68}$, Berliners of all classes might easily find themselves at the wrong end of the police truncheon. Anyone who happened to be in the wrong place at the wrong time was at risk of getting a solid beating when police intervened indiscriminately to maintain public order in public space. Occasionally members of the Bürgertum claimed to have been the victim of police violence or arbitrary arrests, even if the physical attacks suffered by middleclass citizens tended to be much less serious than the ill-treatment commonly inflicted on members of the lower orders.

The main problem was that, in random encounters with the police, members of the Berlin Bürgertum were treated, to a greater extent than previously, in much the same way as the lower orders. They were 'Publikum', the indiscriminate police terminology for anyone who happened to be in the public space, which did not make the kind of social distinctions that many members of the Berlin Bürgertum thought they deserved. While members of the Berlin Bürgertum expected to be treated with respect and while the lower orders demanded to be treated with respect, policemen were repeatedly accused of treating everybody equally poorly. The struggle over positioning in the social hierarchy is revealed most clearly in the numerous complaints about police incivility. Prussian policemen were notorious for their barking, arrogant manner that treated members of the public as military recruits at drill. Numerous complaints about police incivility from pillars of the Berlin society (senior civil servants, high-court judges, and wealthy businessmen) reflect the notoriously authoritarian police attitude to members of the public, but there is another element to the middle-class concerns that seems to be reflected in these complaints :

67 BLA, A. Pr. Br. Rep. 030, Titel 94, No. 8881: Complaints from Rechtsanwalt Friedrich Holtz, 16 October 1912; J. Weiler, Börsenvertreter der Deutschen Bank, 24 February 1913; and Bruno Reichenbach, owner of Berliner Siphon-Fabrik, 7 April 1913.

68 Responses in The Times to the publication of the Royal Commission into the Duties of the Metropolitan police, July 1908; similarly eleven reports on the Metropolitan police published in The Times between 24 December 1908 and 13 January 1909. See also Taylor (2002, pp. 93-94); Lawrence (2004, p. 213). 
namely the social positioning in relation to the plebeian policeman who did not respect the social hierarchy.

The Bürgertum's expectations of socially superiority was at odds with the assertive self-perception of the rank-and-file Schutzmann. Unlike policemen in municipal forces, who were effectively the employees of local elites, the Berlin Schutzmann was a State official under the command of the police president and the interior minister, both appointed by the King. The Berlin Schutzmann was trained to see himself as the embodiment of the Prussian State and defending the authority of the King. Any member of the public who disregarded his orders was considered as attacking the authority of the entire Prussian-German State. The arrogant attitude towards members of the public was exacerbated by the fact that most policemen also had served a long career in the Prussian army within which civilians were regarded as lesser beings who owed respect to the humblest representative of public authority.

Many of the bourgeois complainants were in no mood to accept this police selfperception of superiority. Although there was generally a high degree of deference amongst the German bourgeoisie for anyone linked to the army, this was not the case when it came to the police. It is therefore hardly surprising that confrontations between police and members of the Bürgertum revolved around the question of who had most authority. Bourgeois complainants often made a point of mentioning not only their prestigious civilian profession that clearly placed them in a superior social position to that of the policeman, but they also made a particular point of their own rank as officers of the reserve in the Prussian army or the fact that they were veterans from the Franco-Prussian $\mathrm{War}^{69}$. While their military credentials were not directly relevant to their complaint, they were highly significant in placing the bourgeois officer of the reserve on a superior rank within the military hierarchy to the Schutzmann whose rank had rarely been above that of a non-commissioned officer.

While German liberals freely accepted the government's boasts about the effectiveness of the Berlin Schutzmannschaft in crime fighting and order maintenance, the Bobby became an icon to German Liberals. What the English police model offered was not only a system that empowered members of the public in relation to the police, but also a form of police-public relations wherein policemen observed a polite deferential attitude towards members of the "better classes". If the feeling of complete disempowerment in relation to the police underlay many of the bourgeois complaints, it was not simply a struggle for control: it was also a struggle against any social degradation of the bourgeois in encounters with the socially inferior policeman.

The increasing number of bourgeois complaints should also be seen in the light of a wider critique against the turn taken by Wilhelm II. The enthusiasm generated by the unification was wearing thin and the high hopes for reform and liberalisation which characterised the first years of Wilhelm II's reign were followed by great disappointment over the political direction when his "New Course" political line was replaced by attempts at "personal rule". The police was an obvious target of all that seemed negative about the Wilhelmine reign. In the 1870s and 1880s, intrusive and heavy-handed policing was still acceptable to the majority of the Berlin Bürgertum as a necessary evil to deal with the 'Red Menace'. Moreover, most of the brunt fell on the lower orders. By the turn of the twentieth century the Social Democrats were still considered politically dangerous because of their political muscle and their abil-

69 BLA, A. Pr. Br. Rep. 030, Title 94, No. 8881 (documents 3-7); ibid., 293-297. 
ity to mobilise the masses, but they were not common criminals. As the Social Democrats went out of their way to appear respectable, the police justifications of heavy-handed policing began to sound hollow. Nor did it escape the attention of some middle-class critics that repeated heavy-handed police intervention against peaceful demonstrators could only increase workers' support for the Social Democratic Party. Some began to question the justification and appropriateness of policing methods suggesting that it was counterproductive and inadvertently provided excellent propaganda for the Social Democratic Party ${ }^{70}$.

The police exercise of power was increasingly reducing the bourgeois to the same level as the lower orders. This gradually undermined the support for the police among the Bürgertum. The numerous bourgeois complaints to the Police President and in the press indicate that police managed to alienate not only the groups who were most obviously the target of police attention, but also many individuals who were otherwise most supportive of the social and political order. It did not help that their complaints were met with unrepentant justifications by the police authorities and interior ministry who sought to legitimise even the most blatant police abuse. Yet the main concern of Berlin's bourgeois complainants was not that civil liberties be respected but rather a struggle for their own demands for respect and their opposition to increasing police interference in their private and business affairs.

\section{CONCLUSIONS: RESPONSIVENESS TO COMPLAINTS AND LEGITIMACY OF POLICING}

In comparison with the London Metropolitan police and in spite of some attempts to open up towards the public, the Berlin Schutzmannschaft remained very reluctant to engage with complaining citizens. This reluctance to provide meaningful access for citizens to challenge police behaviour was replicated in the judicial and the administrative complaints mechanisms, and overall the political complaints mechanisms remained much weaker in Germany. Nevertheless it is important to note the increasing frequency and potency of the complaints launched outside the officially recognised procedures through the press, through the Reichstag and through the Prussian Diet. Similarly although Germany remained much weaker than Britain in terms of developing support for complainants through civil liberties groups or well-placed individuals, the Social Democratic Party began to perform such a role even if its means to challenge the police were weak and often ineffective.

It is nevertheless important to recognise the ever-greater tensions between police behaviour and public expectations. Some of those who were most likely to support the regime became alienated, and this gradually undermined the justifications provided by the regime for their policing actions. This was the real contrast with police-public relations in London, which skilfully provided the appearance of responsiveness to citizens' complaints, enough to satisfy the politically significant sections of the population. If, in practice, the heads of the London Metropolitan police turned a blind eye to a good deal of violent and illegal practices, and even if major inquiries into police

70 GStA, H.A.1, Rep. 77, CB S, No 48, Bd. 4, document 1: Allgemeine Beobachter (Essener Anzeiger), 4 May 1910. See also the controversial analysis of von Massow (1894, p. 265). 
practices ended with a degree of whitewash, the apparent responsiveness strengthened the legitimacy of the police and the regime it served. In Berlin, by contrast, the intransigence of the police had the opposite effect, alienating and undermining the legitimacy and respect for the police, and ultimately of the Prussian State.

While Funk is right in observing that Berliners of all classes knew that they were unlikely to get anything out of complaining ${ }^{71}$, this did not deter them from complaining in great numbers. The number of complaints and the social breath of the complainants reveal an aspect of Wilhelmine culture that contradicts the image of the submissive German Untertan: Germans of all creeds and classes challenged authorities, according to their financial means and abilities. Complaints letters often used formulations that accommodated to the expectation of submissive politeness, but it would be wrong to take this at face value: beneath the submissive tone there was self-assertiveness and implicit demands for respect for rights, personal dignity and integrity against police impoliteness, aggressiveness and arbitrariness.

So what did the people of Berlin expect to get out of their complaint letters to the police president? Several outcomes can be identified which made sense of the complaints even if they did not lead to obvious action against the policeman or an apology from the police. First and foremost, the complaint placed the policeman in a fragile position within the police. If there were many complaints against the same policeman, particularly from members of the 'respectable' classes, there was a chance that his superiors would eventually discipline him or sack him - even if the complainant would not be informed and the police authorities would not make it appear that the policeman was disciplined as a result of complaints. For aggrieved citizens who approached the press, there was the pleasure of winning the moral argument, even if the police remained inflexible - at the surface at least.

Behind this logic lies the strengthening sense of justice (Rechtsbewusstsein) among all sections of society. This apparently pointless letter-writing reflects a widespread sense of certain actions of the police being 'wrong' and that the police authorities and the government were on the defensive over the issue of police malpractice. Complaining and revealing the details in the press put the authorities under pressure to come up with some justification, but since the police authorities and interior ministry could be relied upon to provide justifications that were completely ad odds with prevailing conceptions of acceptable police behaviour, the official explanations from the police and interior ministry only contributed to undermining their position and leaving the complainant as the winner of the moral argument. Whereas the apparent responsiveness of the London Metropolitan police was intended to, and often succeeded in, strengthening the legitimacy of the force, the lack of meaningful engagement of the Berlin Schutzmannschaft with complainants contributed to the undermining of its legitimacy, even among the peace-loving, law-abiding and kaisertreue parts of the population.

Anja Johansen

Department of History University of Dundee Nethergate

UK - Dundee DD1 4HN a.m.johansen@dundee.ac.uk

71 Funk (1986, pp. 285-286). 


\section{BIBLIOGRAPHY}

Bartels, B., Polizeilehrbuch, Berlin, Carl Hermann, 1913.

Bailey, D. H., Patterns of Policing : A comparative international analysis, New Brunswick, Rutgers University Press, 1985.

Bailey, D. H., Preface, in Goldsmith, A. J. (ed.), Complaints against the police: the trend toward external review, Oxford, Clarendon, 1991.

Berlière, J.-M., L'institution policière en France sous la Troisième République, 1875-1914, Unpublished Doctoral Thesis, University of Bourgogne, Dijon, 1991.

Born, W., Ein Beitrag zur Reform der inneren Verwaltung, Die Polizei, 1910, 6, pp. 439-442.

Bruneteaux, P., Maintenir l'ordre, Paris, Presses de la FNSP, 1996.

Clark, C., Iron Kingdom: the rise and downfall of Prussia, 1600-1947, London, Allan Lane, 2006.

Dwyer, P. G., The rise of Prussia, 1770-1830, Harlow, Longman, 2000.

Eiben, H., Polizei-Taschen-Lexicon : Sammlung von Reichs- und Landesgesetzen nebst Ausführungs- und Polizei-Verordnungen und zahlreichen Erkenntnissen der höchsten Gerichte, Köln, Kölner Verlag, 1903.

Eley, G., Blackbourn, D., The peculiarities of German history : bourgeois society and politics in nineteenth-century Germany, Oxford, OUP, 1984.

Emsley, C., Policing in its context, 1750-1870, London, Macmillan, 1983.

Emsley, C., "The Thump of Wood on a Swede Turnip": Police violence in $19^{\text {th }}$ century England, Criminal Justice History, 1985, 6, pp. 125-149.

Emsley, C., The English Police: A Political and Social History, Harlow, Peason, 1996 ( $2^{\text {nd }}$ ed.).

Emsley, C., (2003) Conclusion: Policemen on a Dark Continent in an Age of Extremes, in Oram, G., Conflict and Legality: Policing mid-twentieth century Europe, London, Francis Boutle, 2003, pp. 192-212.

Emsley, C., (2004) Control and Legitimacy: The Police in Comparative Perspective since circa 1800, in Emsley C., Johnson E. A., Spierenburg P. (eds), Social control in Europe 1800-2000, Columbus, Ohio State University, 2004, pp. 193-209.

Engelhardt, G., Rechte und Pflichten der Staatsbürger, Berlin, Liebelschen, 1912.

Evans, R. J., Rethinking German History, London, HarperCollins, 1987.

Fillieule, O., Stratégies de la rue : les manifestations en France, Paris, Presses de Science po, 1997.

Friedrich, K., The other Prussia : Royal Prussia, Poland and liberty, 1569-1772, Cambridge, CUP, 2000.

Funk, A., Polizei und Rechtsstaat: Die Entstehung des Staats-rechtlichen Gewaltmonopol in Preußen, 1848-1918, Frankfurt a. M, Campus Verlag, 1986a.

Funk, A. Polizei und Rechtstaat: Die Entwicklung des staatlichen Gewalt-monopol in Preussen, 1848-1918, Frankfurt a. M., Campus, 1986b.

Gerland, O., Der Polizei-Dienst bei städtischen Polizei-Verwaltung in Preußen, Berlin, Carl Hermann, 1895.

Geyger, A., Der Polizeidienst. Ein Hilfs- und Nachschlagebuch für preußische Polizeibeamte, Berlin, Kameradschaft, 1909.

Goldsmith, A. J., External review and self-regulation: police accountability and the dialectic of complaints procedures, in Goldsmith, A. J. (ed.), Complaints against the police: the trend toward external review, Oxford, Clarendon, 1991, pp. 13-57. 
Goldsmith, A. J., What's wrong with complaint investigations? Dealing with difference differently in complaints against the police, Criminal Justice Ethics, 1996, 15, 1, pp. 36-55.

Goldsmith, A. J., Lewis, C. (eds), Civilian Oversight of Policing : Governance, Democracy and Human Rights, Oxford, Hart Publishing, 2000.

Hall, A., Scandal, Sensation and Social Democracy: the SPD press and Wilhelmine Germany, London, Sinclair-Stevenson, 1977.

Howard V., A Police Code and Manual of the Criminal Law, London, Cassell \& Co., 1883.

Jessen, R., Polizei im Industrierevier: Modernisierung und Herrschaftspraxis im westfälischen Ruhrgebiet, 1848-1918, Göttingen, Vandenhoeck \& Rupreckt, 1991.

Johansen, A., A Process of Civilisation? Legitimisation of violent policing in Prussian and French police manuals and instructions, 1880-1914, Revue of European History, 2007, 14, 1, pp. 49-71.

Johnson, E. A., Urbanisation and Crime, Cambridge, CUP, 1995.

HMSO, Report of the Royal Commission upon the duties of the Metropolitan Police, London, HMSO, 1908 (Vols. 1-2).

Kampf, B. von, Beschwerde und Klage sowie sonstige Rechtsmittel gegen polizeiliche Verfügungen und Zwangsmaßregeln, Berlin, Heines, 1894.

Kocka, J., Mitchell, A. (eds), Bourgeois society in nineteenth-century Europe, Oxford, Berg, 1993.

Lawrence, P., Policing the Poor in England and France, 1850-1900, in Emsley, C., Johnson, E. A., Spierenburg, P. (eds), Social control in Europe 1800-2000, Columbus, Ohio State University, 2004, pp. 210-225.

Lemke, R., Die Preussische Executiv-Polizei. Wie sie war, wie sie ist und wie sie sein müsste: Auf Grund amtlicher Quellen und verschiedener Schriftwerke zusammengeschellt, verfasst und herausgegeben, Osnabrück, Liesecke, 1904.

Levinger, M., Enlightened nationalism: The transformation of Prussian political culture, 1806-1848, Oxford, OUP, 2000.

Lindenberger, T., Straßenpolitik: zur Sozialgeschichte der öffentlichen Ordnung in Berlin, 1900 bis 1914, Bonn, Dietz, 1995.

Lüdtke, A., "Gemeinwohl”, Polizei und "Festungspraxis": Staatsliche Gewaltsamkeit und innere Verwaltung in Preußen, 1815-1850, Göttingen, Vandenhoeck \& Rupreckt, 1982.

MacDonogh, G., Prussia : the perversion of an idea, London, Mandarin, 1995.

McAdam, D., Tarrow, S., Chrles Tilly, C., Dynamics of Contention, Cambridge, CUP, 2001.

Massow, C. von, Reform oder Revolution, Berlin, Otto Liebmann, 1894.

Miller, W. R., Cops and Bobbies: Police authority in New York and London, 1830-1870, Chicago, London, Chicago University Press, 1973.

Müller, P., Auf der Suche nach dem Täter: Die öffentliche Dramatisierung von Verbrechen im Berlin des Kaiserreichs, Frankfurt a. M., Campus Verlag, 2005.

Nipperdey, T., Deutsche Geschichte, 1800-1866: Bürgerwelt und Starker Staat, Munich, Beck, 1987.

Nipperdey, T., Deutsche Geschichte, 1866-1918: Arbeiterwelt und Bürgergeist, Munich, Beck, 1991.

Prenzler, T., Lewis, C., Performance indicators for police oversight agencies, Australian Journal of Public Administration, 2005, 64, 2, pp. 552-568.

Repp, K., Reformers, critics, and the paths of German modernity: anti-politics and the search for alternatives, 1890-1914, Cambridge, MA, Harvard University Press, 2000.

Segger, J., Executiv-Polizei und Publikum. Ein Wort zur Klärung und gegenseitigen Würdigung, Münden, Reinhold Werther, 1898. 
Sampson, F., de Silva, N., Police Conduct, Compalints \& Efficiency, London, Blackstone, 2001.

Smith, G., A most enduring problem: police complaints reform in England and Wales, Journal of Social Policy, 2006, 35, pp. 121-141.

Spencer, E. G., Police and the Social Order in German Cities : The Düsseldorf District, 18481914, DeKalb, Northern Illinois University Press, 1992.

Storch, R. D., The Plague of the Blue Locust. Police Reform and Popular Resistance in Northern England, 1840-1857, International Review of Social History, 1975, 20, pp. 61-90.

Taylor, D., The new police in nineteenth-century England: Crime, conflict and control, Manchester, Manchester University Press, 1997.

Taylor, D., Policing the Victorian Town, Basingstoke, Macmillan, 2002.

Tilly, C., Dynamics of Contention, Cambridge, CUP, 2001.

Tilly, C., Contention and Democracy in Europe, 1650-2000, Cambridge, CUP, 2003.

Walker, S., Police Accountability: The role of citizen oversight, Belmont, Wadsworth, 2001.

Weinberger, B., The Police and the Public in mid-nineteenth-century Warwickshire in Bailey, V. (ed.), Policing and Punishment in nineteenth-century Britain, London, Croom Helm, 1981, pp. 65-93. 